\title{
Spiroplasma velocicrescens sp. nov., from the Vespid Wasp Monobia quadridens
}

\author{
MEGHNAD KONAI, ${ }^{1}$ ROBERT F. WHITCOMB, ${ }^{1 *}$ JOSEPH G. TULLY, ${ }^{2}$ DAVID L. ROSE, ${ }^{2}$ PATRICIA CARLE, ${ }^{3}$ \\ JOSEPH M. BOVÉ, ${ }^{3}$ ROBERTA B. HENEGAR, ${ }^{1}$ KEVIN J. HACKETT, ${ }^{1}$ TRUMAN B. CLARK, ${ }^{1}$ \\ AND DAVID L. WILLIAMSON ${ }^{4}$
}

Insect Biocontrol Laboratory, Beltsville Agricultural Research Center, Agricultural Research Service, U.S. Department of Agriculture, Beltsville, Maryland 20705'; Mycoplasma Section, Laboratory of Molecular Microbiology, National Institute of Allergy and Infectious Diseases, Frederick Cancer Research Facility, Frederick, Maryland 217012; Laboratoire de Biologie Cellulaire et Moléculaire, Institut Nationale de la Recherche Agronomique, Pont-de-la-Maye, France ${ }^{3}$; and Department of Anatomical Sciences, State University of New York, Stony Brook, New York $11794^{4}$

\begin{abstract}
Spiroplasma strain MQ-4 ${ }^{\mathrm{T}}$ ( $\mathrm{T}=$ type strain), which was isolated from the hemolymph of the vespid wasp Monobia quadridens, was serologically distinct from other spiroplasma species, groups, putative groups, and subgroups. Each strain MQ-4 ${ }^{\mathrm{T}}$ cell was helical and motile and was surrounded by a single cytoplasmic membrane; there was no evidence of a cell wall. The strain grew well in $1 \%$ serum fraction medium, as well as in SM-1, M1D, and SP-4 liquid media, under both aerobic and anaerobic conditions. Strain MQ-4 ${ }^{\mathrm{T}} \mathrm{grew}$ at temperatures ranging from 10 to $41^{\circ} \mathrm{C}$ but did not grow at $43^{\circ} \mathrm{C}$. The strain grew optimally at $37^{\circ} \mathrm{C}$ with a doubling time of $0.6 \mathrm{~h}$, the shortest doubling time recorded for any spiroplasma. Strain MQ-4 ${ }^{\mathrm{T}}$ catabolized glucose and arginine but did not hydrolyze urea. The guanine-plus-cytosine content of the DNA was about 27.5 $\pm 1 \mathrm{~mol} \%$. The genome size was $1,480 \mathrm{kbp}(940 \mathrm{MDa})$. Strain MQ-4 (= ATCC 35262) is designated the type strain of a new species, Spiroplasma velocicrescens.
\end{abstract}

The genus Spiroplasma (31), which originally was considered a taxon that contains insect-borne pathogens of plant phloem, was later shown by Clark and his associates $(6,7)$ to be associated primarily with insects. As the true affiliations of members of this genus were discovered, unique features that characterized each new group emerged. However, for some time, it appeared that the group XI spiroplasmas, represented by strain MQ-4 ${ }^{\mathrm{T}}$ ( $\mathrm{T}=$ type strain), which was isolated from the gut of the predaceous wasp Monobia quadridens, might have no unusual properties. This host had yielded several other spiroplasma taxa (6), including the group VII organism Spiroplasma monobiae MQ-1 (28), and it was felt that the spiroplasmas could have been acquired from prey insects (12). However, Konai et al. (14) have recently shown that strain MQ- $4^{\mathrm{T}}$ is the fastest growing spiroplasma that has been assigned to a group.

In this paper we present the results of a taxonomic study of strain MQ-4 ${ }^{\mathrm{T}}$, in accordance with the proposed (13) minimal requirements for assignment of binomial names to mollicutes. We conclude that strain MQ-4, the type strain of group XI, represents a new species, Spiroplasma velocicrescens.

\section{MATERIALS AND METHODS}

Spiroplasma strains. Clark originally isolated strain MQ- $4^{\mathrm{T}}$ by macerating the gut contents of vespid wasps ( $M$. quadridens) collected in Maryland (6). Some of the genomic and serologic characteristics of this organism have been reported previously $(3,23,27,31)$. Strain MQ-4 $4^{\mathrm{T}}$ was purified by classical filtration-cloning techniques (21). Representative strains of the 23 recognized groups and eight subgroups $(11,23)$, including the type strains of the 15 previously recognized species and seven new strains, each representing a putative new group $(26,29)$, were used in various parts of this study.

Culture media and cultivation techniques. Strain MQ-4 ${ }^{\mathrm{T}}$ was selected from a population of helical cells growing in a primary culture in SM-1 liquid medium (25) at $30^{\circ} \mathrm{C}$. After several early broth passages, the isolate was lyophilized. Later, the dried culture was revived and passed twice in SM-1 broth at $30^{\circ} \mathrm{C}$ before triple cloning. After the last cloning, a strain derived from a single colony was designated MQ $-4^{\mathrm{T}}$ and was used in characterization studies. The other

\footnotetext{
* Corresponding author.
}

culture media used included M1D and SP-4 media and serum fraction broth supplemented with $1 \%$ bovine serum fraction. A solid formulation of each of these media was prepared by adding Noble agar (Difco Laboratories, Detroit, Mich.) to a final concentration of $0.8 \%$. Agar cultures were incubated at $30^{\circ} \mathrm{C}$, either aerobically with 5\% carbon dioxide (GasPak system; BBL Microbiology Systems, Cockeysville, Md.) or anaerobically (hydrogen GasPak system).

Temperature requirements. Temperature requirements for growth were assessed by preparing 10 -fold dilutions of strain MQ-4 $4^{\mathrm{T}}$ in M1D broth. One series of dilutions was incubated at each of 10 temperatures $(5,10,15,20,25,30,32$, 37,41 , and $43^{\circ} \mathrm{C}$ ). Doubling times were computed by the method of Konai et al. (14).

Morphological and ultrastructural studies. Cells of strain MQ-4 $4^{\mathrm{T}}$ in liquid cultures in the early logarithmic phase were observed by dark-field microscopy at a magnification of $\times 1,250$. For electron microscopy, the strain was grown in approximately $20 \mathrm{ml}$ of broth and pelleted by centrifugation. The pelleted cells were fixed for $2 \mathrm{~h}$ in $3 \%$ glutaraldehyde, postfixed in $1 \%$ osmium tetroxide for 1 $\mathrm{h}$, dehydrated in acetone, embedded in Epon, sectioned, and stained with $1 \%$ aqueous uranyl acetate and Reynold's lead citrate (30).

Sterol requirement. The sterol requirement for growth of spiroplasma strain MQ- $4^{\mathrm{T}}$ was demonstrated by the direct broth method (22) and a recently described dilution method (18). For the direct broth test we used one $100-\mathrm{ml}$ bottle of regular serum-containing medium as a positive control, three bottles of serumfree medium for reagent controls, and four bottles of serum-free medium containing different amounts of cholesterol. All of the bottles were inoculated with a log-phase culture of strain MQ- $4^{\mathrm{T}}$ and were incubated at $30^{\circ} \mathrm{C}$ until the media acidified. The cells were harvested by centrifugation at $15,000 \mathrm{rpm}$ for $20 \mathrm{~min}$, washed in phosphate-buffered saline ( $\mathrm{pH} \mathrm{7.5),} \mathrm{and} \mathrm{recentrifuged,} \mathrm{and} \mathrm{the} \mathrm{cell}$ pellets were assayed to determine their protein contents by using the Bio-Rad DC protein assay (Bio-Rad Laboratories, Richmond, Calif.). The total amount of protein was used as an indication of spiroplasma growth in the various media.

Tests to determine biological and biochemical properties. The procedures used to study carbohydrate fermentation $(1,17)$, arginine catabolism (2), urea hydrolysis (16), hemadsorption (10), and film and spot production (9) have been described previously. Filtration characteristics were determined by serially filtering log-phase cultures in M1D broth, using techniques described previously (21). Serological tests. Antiserum to strain MQ- $4^{\mathrm{T}}$ was raised in rabbits as previously described (32). Hyperimmune antisera to all previously described Spiroplasma species, groups, putative groups, and subgroups were obtained from the reference collections at the Beltsville Agricultural Research Center and the Mycoplasma Section of the National Institute of Allergy and Infectious Diseases laboratory in Frederick, Md. These antisera and strain MQ-4 ${ }^{\mathrm{T}}$ were tested with standard disc growth inhibition tests $(8,27)$ by using M1D agar plates incubated aerobically at $30^{\circ} \mathrm{C}$. For metabolism inhibition $(20,32)$ and deformation tests we also used previously described protocols (32)

Genomic analysis. One-liter log-phase cultures of strain MQ-4 ${ }^{\mathrm{T}}$ in M1D medium were harvested by centrifugation at $20,000 \times g$ for $30 \mathrm{~min}$. The pellets were 


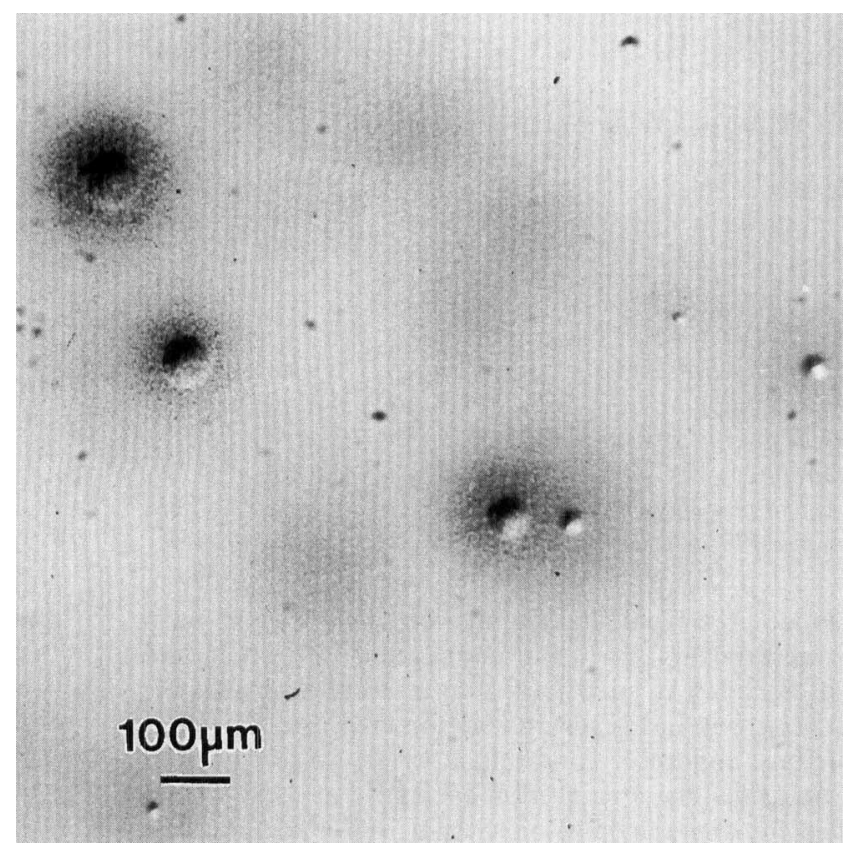

FIG. 1. Colonies of strain MQ-4 $4^{\mathrm{T}}$ on $20 \%$ horse serum agar $(0.8 \%$ Noble agar) after 4 days of incubation at $30^{\circ} \mathrm{C}$.

washed in phosphate-buffered saline ( $\mathrm{pH} 7.5$ ), recentrifuged, and denatured with sodium dodecyl sulfate. Chromosomal DNA was purified further as described by Carle et al. (4). The guanine-plus-cytosine $(G+C)$ content of purified strain MQ-4 ${ }^{\mathrm{T}}$ DNA was determined by buoyant density, melting temperature, and high-performance liquid chromatography methods (5). Purified DNA from Spiroplasma citri $\mathrm{R} 8 \mathrm{~A} 2$ ( $\mathrm{G}+\mathrm{C}$ content, $26 \pm 1 \mathrm{~mol} \%$ ) was used as a reference DNA in all procedures. The genome size was determined (3) by performing pulsedfield gel electrophoresis with a logarithmic-phase whole-cell culture of strain MQ-4 ${ }^{T}$ embedded in low-melting-point SeaPlaque agarose blocks. $S$. citri R8A2 processed and embedded in a similar way was used as a standard (genome size, approximately $1,820 \mathrm{kbp}[1,156 \mathrm{MDa}])$.

\section{RESULTS AND DISCUSSION}

Cultural and morphological properties. Strain MQ-4 ${ }^{\mathbf{T}}$ grew well in liquid SM-1, M1D, and SP-4 media and on solid media prepared from these formulations. The strain also grew in conventional mycoplasma media containing horse serum (Edward formulation) or bovine serum fraction. Growth occurred at 10 to $41^{\circ} \mathrm{C}$, and optimum growth occurred at $37^{\circ} \mathrm{C}$. The doubling times in M1D medium at 10, 15, 20, 25, 30, 32, 37, and $41^{\circ} \mathrm{C}$ were $20.4,6.9,3.3,1.7,1.1,0.7,0.6$, and $1.7 \mathrm{~h}$, respectively. Colonies of strain MQ-4 ${ }^{\mathrm{T}}$ on SP-4 agar (Fig. 1) were diffuse; colonies having "fried-egg" morphology were never observed. Growth of strain MQ-4 ${ }^{\mathrm{T}}$ on solid medium was observed on agar plates incubated aerobically at $30^{\circ} \mathrm{C}$ or when the plates were placed in GasPak systems with carbon dioxide atmospheres. No growth occurred on agar media under anaerobic conditions. Logarithmic-phase cultures of strain $\mathrm{MQ}-4^{\mathrm{T}}$ in SP-4 medium examined by dark-field microscopy contained numerous long helical motile filaments, most of which had six or more turns. Thin sections of the organism revealed pleomorphic cells with no evidence of a cell wall (Fig. 2). Representative cells were about 200 to $300 \mathrm{~nm}$ in diameter, and each cell was surrounded by a single cytoplasmic membrane.

Sterol requirement. The response of strain MQ $-4^{\mathrm{T}}$ to cholesterol supplementation of serum-free M1D medium is shown in Table 1. No growth occurred in base broth alone, but growth was enhanced when 5 to $20 \mu \mathrm{g}$ of cholesterol per ml was included in the medium. Similar responses (data not shown) were observed when various concentrations ( 1 to $17 \%$ ) of fetal bovine serum were added to SP-4 base broth. Strain MQ-4T did not exhibit sustained growth when serial subcultures were made in serum-free broth or when $0.04 \%$ Tween 80 was added to this formulation (18). However, strain MQ-4 $4^{\mathrm{T}}$ could be passed continuously in serum-containing medium, indicating that sterol was required for growth.

Biochemical and biological properties. Strain MQ $-4^{\mathrm{T}}$ produced acid from glucose and hydrolyzed arginine, but no evidence of urea hydrolysis was observed. Strain MQ- $4^{\mathrm{T}}$ was positive for film and spot production, but colonies of the organism on an agar medium did not hemadsorb guinea pig erythrocytes. Passage of broth cultures of strain MQ- $4^{\mathrm{T}}$ through 450 - or 300-nm-pore-size membrane filters did not reduce the viable cell titer $\left(10^{8}\right.$ color-changing units $\left./ \mathrm{ml}\right)$. The titer of a broth culture filtrate obtained after passage through a 220-nm-poresize membrane was about 10 -fold lower $\left(10^{7}\right.$ color-changing units/ml); a 100 -nm-pore-size membrane filtrate did not contain viable cells.

Serological tests. The results of growth inhibition, metabolism inhibition, and spiroplasma deformation tests indicated that strain MQ- $4^{\mathrm{T}}$ was not related serologically to representatives of previously described Spiroplasma groups or species or to seven ungrouped representatives of putative new groups (29).

Genome size and DNA base composition. The base compositions ( $\mathrm{G}+\mathrm{C}$ contents) of strain MQ- $4^{\mathrm{T}}$ DNA were 27.5, 27.3, and $27.9 \mathrm{~mol} \%$ as determined by the buoyant density, melting temperature, and high-pressure liquid chromatography techniques, respectively. The genome size was $1,480 \mathrm{kbp}$ (940 MDa).

Habitat. The single strain described in this paper was isolated directly from the gut of the vespid wasp $M$. quadridens. Most mollicutes cultivated from insects have been isolated from guts $(6,12)$. Residence in the gut of a predaceous insect could simply reflect acquisition from prey. Some mollicutes that reside in insect hemolymph, such as Spiroplasma melliferum (7) and Spiroplasma apis (15), reduce the longevity of the host. Strain MQ-4 ${ }^{\mathrm{T}}$, like other insect gut spiroplasmas, is not known to be pathogenic to its insect host.

Diagnosis and significance. Like other Spiroplasma species $(24,31), S$. velocicrescens can be identified by serological tests. In metabolism inhibition and deformation tests, it exhibits, at most, minor one-way crosses with sera to all previously described Spiroplasma species, groups, subgroups, and putative groups (29). There is no known close relative; the group VII organism strain MQ-1 (S. monobiae), which was isolated from the same host, has a G+C content of $28 \pm 1 \mathrm{~mol} \%$ and a genome size of $657 \mathrm{MDa}$, values that differ from the strain MQ- $4^{\mathrm{T}}$ values. The rapid growth of strain MQ- $4^{\mathrm{T}}$ and its optimum temperature $\left(37^{\circ} \mathrm{C}\right)$ are by no means unique. Ungrouped strain HYOS-1 (29) grows almost as fast (doubling time at the optimum temperature $\left[32^{\circ} \mathrm{C}\right], 0.7 \mathrm{~h}$ ), and strains of Spiroplasma floricola, S. apis, Spiroplasma chinense, and Spiroplasma culicicola and representatives of groups VIII and XII also grow very rapidly (14). The optimum temperature for 14 strains, representing nine groups of spiroplasmas, is $37^{\circ} \mathrm{C}(14)$.

Taxonomic placement. The properties described above for strain MQ $-4^{\mathrm{T}}$ fulfill proposed criteria for species belonging to the class Mollicutes, including absence of a cell wall, filterability, and penicillin resistance. The growth requirement for sterol or serum, the inability to utilize urea, and the helicity and motility of strain MQ-4T place this organism in the family Spiroplasmataceae (19) and the genus Spiroplasma. Finally, a serologic comparison of strain MQ-4 $4^{\mathrm{T}}$ with other Spiroplasma species and with other unclassified spiroplasma strains that 


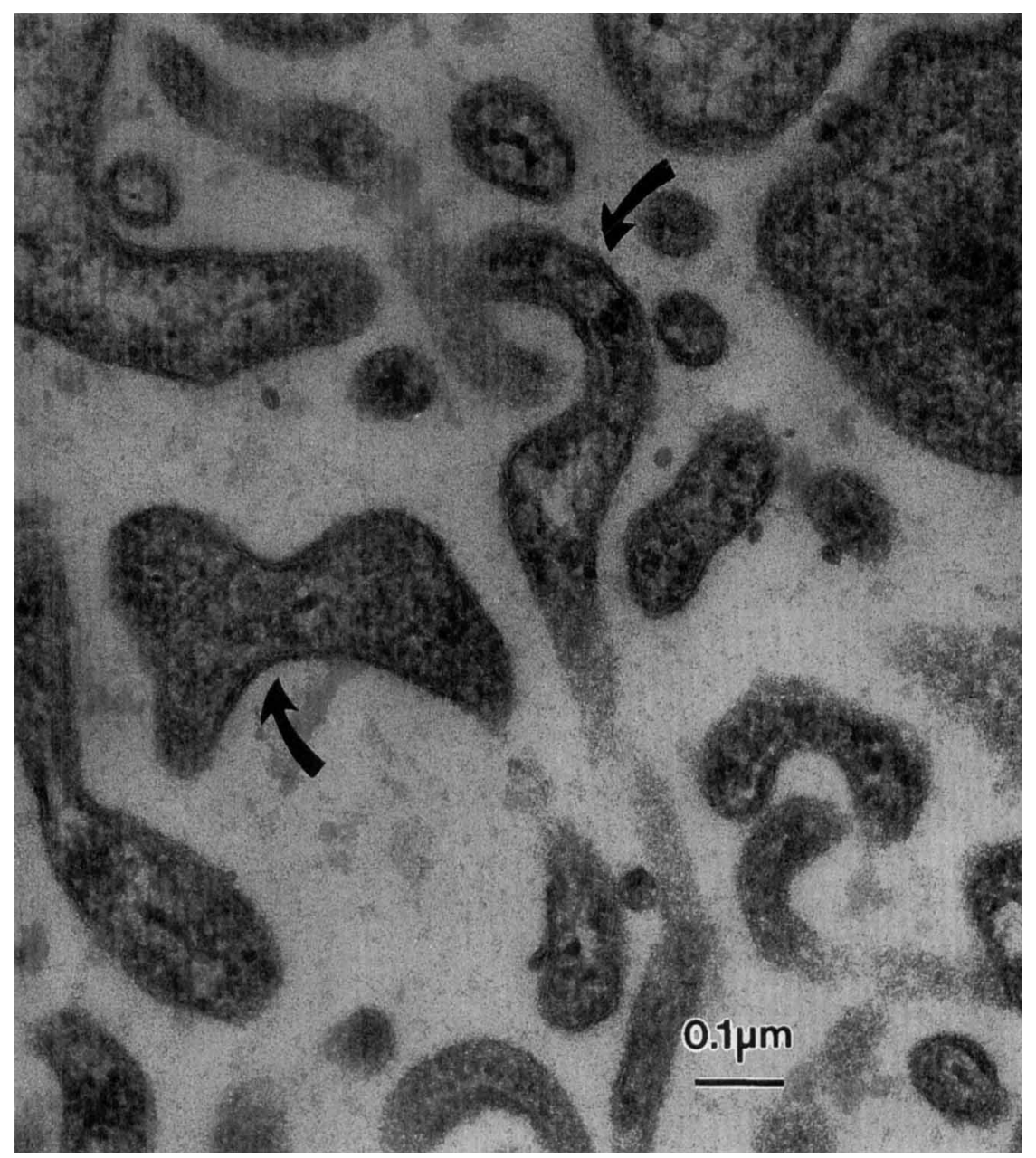

FIG. 2. Electron micrograph of a sectioned and stained cell pellet of strain MQ-4T. Sections were stained with $2 \%$ aqueous uranyl acetate and Reynold's lead citrate. The arrows indicate the unit membrane.

represent putative species revealed the uniqueness of the new insect strain. Therefore, we propose the name Spiroplasma velocicrescens for this organism.

Description of Spiroplasma velocicrescens sp. nov. Spiroplasma velocicrescens (ve.lo.ci. cres'cens. $L$. adj. veloci, fast; $L$. part. crescens, growing; M. L. n. part. velocicrescens, fast grow-

TABLE 1. Growth responses of strain MQ- $4^{\mathrm{T}}$ in the presence of different concentrations of cholesterol

\begin{tabular}{lcc}
\hline \multicolumn{1}{c}{ Medium } & $\begin{array}{c}\text { Cholesterol concn } \\
(\mu \mathrm{g} / \mathrm{ml})\end{array}$ & $\begin{array}{c}\mathrm{Amt} \text { of protein } \\
(\mathrm{mg} / 100 \mathrm{ml})\end{array}$ \\
\hline 17\% fetal bovine serum in SP-4 broth & 0 & 2.16 \\
Serum-free broth & 0 & $\mathrm{IG}^{a}$ \\
Serum-free broth containing palmitic & 0 & 0.42 \\
acid $(10 \mu \mathrm{g} / \mathrm{ml})$ and albumin $(1 \%)$ & & \\
Serum-free broth containing palmitic & 0 & 0.17 \\
acid $(10 \mu \mathrm{g} / \mathrm{ml})$, albumin (1\%), and & & \\
Tween 80 (0.01\%) & 1.0 & 0.76 \\
& 5.0 & 0.98 \\
& 10.0 & 1.34 \\
& 20.0 & 1.80 \\
\hline
\end{tabular}

${ }^{a}$ IG, insufficient growth for detection. ing). Cells are helical, motile filaments, vary from 200 to 300 $\mathrm{nm}$ in diameter, and lack cell walls. Colonies on solid medium containing $0.8 \%$ Noble agar are diffuse and never have a friedegg appearance.

Chemoorganotroph. Acid is produced from glucose. Hydrolyzes arginine. Does not hydrolyze urea.

Film and spot reaction negative. Does not hemadsorb guinea pig erythrocytes.

Cholesterol or serum is required for growth.

The temperature range for growth is 10 to $41^{\circ} \mathrm{C}$; the doubling time at $37^{\circ} \mathrm{C}$, the optimum temperature, is $0.6 \mathrm{~h}$.

Serologically distinct from previously described Spiroplasma species. Isolated from the gut of the vespid wasp $M$. quadridens. Pathogenicity for insects has not been determined.

The $\mathrm{G}+\mathrm{C}$ content of the DNA is $27.5 \pm 1 \mathrm{~mol} \%$. The genome size is $1,480 \mathrm{kbp}$ (940 MDa).

The type strain is MQ-4 (= ATCC 35262).

\section{ACKNOWLEDGMENT}

We thank Mark Aronoff of the Department of Linguistics, State University of New York at Stony Brook, for his advice concerning the Latin name. 


\section{REFERENCES}

1. Alluotto, B. B., R. G. Wittler, C. O. Williams, and J. E. Faber. 1970. Standardized bacteriologic techniques for the characterization of Mycoplasma species. Int. J. Syst. Bacteriol. 20:35-58

2. Barile, M. F. 1983. Arginine hydrolysis. Methods Mycoplasmol. 1:345-349.

3. Carle, P., F. Laigret, J. G. Tully, and J. M. Bové. 1995. Heterogeneity of genome sizes within the genus Spiroplasma. Int. J. Syst. Bacteriol, 45:178181.

4. Carle, P., C. Saillard, and J. M. Bové. 1983. DNA extraction and purification. Methods Mycoplasmol. 1:295-299.

5. Carle, P., C. Saillard, and J. M. Bové. 1983. Determination of guanine plus cytosine content of DNA. Methods Mycoplasmol. 1:301-308.

6. Clark, T. B. 1982. Spiroplasmas: diversity of arthropod reservoirs and hostparasite relationships. Science 217:57-59.

7. Clark, T. B., R. F, Whitcomb, J. G. Tully, C. Mouches, C. Saillard, J. M Bové, H. Wróblewski, P. Carle, D. L. Rose, R. B. Henegar, and D. L. Williamson. 1985. Spiroplasma melliferum, a new species from the honeybee (Apis mellifera). Int. J. Syst. Bacteriol. 35:296-308.

8. Clyde, W. A., Jr. 1983. Growth inhibition tests. Methods Mycoplasmol. 1:405-410.

9. Freundt, E. A. 1983. Film and spot production. Methods Mycoplasmol. 1:373-374.

10. Gardella, R. S., and R. A. DelGiudice. 1983. Hemagglutination, hemadsorption, and hemolysis. Methods Mycoplasmol. 1:379-384.

11. Guo, Y. H., T. A. Chen, R. F. Whitcomb, D. L. Rose, J. G. Tully, D. L. Williamson, X. D. Ye, and Y. X. Chen. 1990. Spiroplasma chinense sp. nov. from flowers of Calystegia hederacea in China. Int. J. Syst. Bacteriol. 40:421425.

12. Hackett, K. J., and T. B. Clark. 1989. Ecology of spiroplasmas. Mycoplasmas 5:113-200.

13. International Committee on Systematic Bacteriology Subcommittee on the Taxonomy of Mollicutes. 1979. Proposal of minimal standards for descriptions of new species of the class Mollicutes. Int. J. Syst. Bacteriol. 29:172-180.

14. Konai, M., E. A. Clark, and R. F. Whitcomb. 1992. Temperature ranges and optima of spiroplasmas. IOM Lett. 2:137.

15. Mouches, C., J. M. Bové, J. Albisetti, T. B. Clark, and J. G. Tully. 1982. A spiroplasma of serogroup IV causes a May-disease-like disorder of honeybees in southwestern France. Microb. Ecol. 8:387-399.

16. Razin, S. 1983. Urea hydrolysis. Methods Mycoplasmol. 1:351-353.

17. Razin, S., and V. P. Cirillo. 1983. Sugar fermentation. Methods Mycoplasmol. 1:337-343.
18. Rose, D. L., J. G. Tully, J. M. Bové, and R. F. Whitcomb. 1993. A test for measuring growth responses of mollicutes to serum and polyoxyethylene sorbitan. Int. J. Syst. Bacteriol. 43:527-532.

19. Skripal, I. G. 1983. Revival of the name Spiroplasmataceae fam. nov., nom rev., omitted from the 1980 Approved Lists of Bacterial Names. Int. J. Syst. Bacteriol. 33:408.

20. Taylor-Robinson, D. 1983. Metabolism inhibition tests. Methods Mycoplasmol. 1:411-417.

21. Tully, J. G. 1983. Cloning and filtration techniques for mycoplasmas. Methods Mycoplasmol. 1:173-177.

22. Tully, J. G. 1983. Tests for digitonin sensitivity and sterol requirement. Methods Mycoplasmol. 1:355-362.

23. Tully, J. G., D. L. Rose, E. Clark, P. Carle, J. M. Bové, R. B. Henegar, R. F. Whitcomb, D. E. Colflesh, and D. L. Williamson. 1987. Revised group classification of the genus Spiroplasma (class Mollicutes), with proposed new groups XII to XXIII. Int. J. Syst. Bacteriol. 37:357-364.

24. Tully, J. G., and R. F. Whitcomb. 1991. The genus Spiroplasma, p. 1960 1980. In A. Balows, H. G. Trüper, M. Dworkin, W. Harder, and K. H. Schleifer (ed.), The prokaryotes, 2nd ed., vol. 2. Springer-Verlag, New York

25. Whitcomb, R. F. 1983. Culture media for spiroplasmas. Methods Mycoplasmol. 1:147-158.

26. Whitcomb, R. F, J. M. Bové, T. A. Chen, J. G. Tully, and D. L. Williamson. 1987. Proposed criteria for an interim serogroup classification for member of the genus Spiroplasma (class Mollicutes). Int. J. Syst. Bacteriol. 37:82-84.

27. Whitcomb, R. F., J. G. Tully, P. McCawley, and D. L. Rose. 1982. Application of the growth inhibition test to Spiroplasma taxonomy. Int. J. Syst. Bacteriol 32:387-394.

28. Whitcomb, R. F., J. G. Tully, D. L. Rose, P. Carle, J. M. Bové, R. B. Henegar, K. J. Hackett, T. B. Clark, M. Konai, J. Adams, and D. L. Williamson. 1993 Spiroplasma monobiae sp. nov. from the vespid wasp Monobia quadridens (Hymenoptera: Vespidae). Int. J. Syst. Bacteriol. 43:256-260.

29. Whitcomb, R. F, J. G. Tully, D. L. Williamson, J. M. Bové, F, E. French, M. Konai, G. Gasparich, M. L. Abalain-Colloc, C. Saillard, C. Chastel, P. Carle, D. L. Rose, R. B. Henegar, E. A. Clark, and K. J. Hackett. 1992. Revised classification of spiroplasmas. IOM Lett. 2:135.

30. Williamson, D. L. 1983. Specialized electron microscopic techniques for spiroplasmas in plant and insect tissues. Methods Mycoplasmol. 1:71-76.

31. Williamson, D. L., J. G. Tully, and R. F. Whitcomb. 1989. The genus Spiroplasma. Mycoplasmas 5:71-111.

32. Williamson, D. L., and R. F. Whitcomb. 1983. Special serological tests for spiroplasma identification. Methods Mycoplasmol. 2:249-259. 